\title{
PERKEMBANGAN DAN PROYEKSI PRODUKSI DAN KONSUMSI BERAS DI NUSA TENGGARA BARAT
}

\section{DEVELOPMENT AND PROJECTION OF RICE PRODUCTION AND CONSUMPTION IN WEST NUSA TENGGARA}

\author{
Sopiatun Zohdi Nur, Taslim Sjah dan FX. Edy Fernandez \\ Program Studi Agribisnis Fakultas Pertanian Universitas Mataram
}

\begin{abstract}
ABSTRAK
Penelitian ini bertujuan untuk (a) menganalisis perkembangan produksi dan konsumsi beras di Nusa Tenggara Barat (b) menganalisis metode peramalan yang tepat untuk memproyeksikan produksi dan konsumsi beras di Nusa Tenggara Barat, dan (c) memproyeksikan produksi dan konsumsi beras di Nusa Tenggara Barat tahun 2019-2023. Penelitian ini menggunakan metode deskriptif dengan unit analisis yaitu Provinsi Nusa Tenggara Barat. Jenis data yang digunakan merupakan data kuantitatif dan kualitatif dengan sumber data sekunder. Analisis data yang digunakan diantaranya adalah metode deskriptif, metode Double Exponential Smoothing oleh Holt dan Metode Trend Least Square dan metode Mean Absolute Percentage Error (MAPE). Hasil penelitian menunjukkan bahwa: (1) perkembangan produksi beras di Nusa Tenggara Barat dalam kurun waktu 14 tahun terakhir (2005-2018) mengalami fluktuasi, namun secara umum mengalami peningkatan. Produksi beras terendah di NTB terjadi pada tahun 2005 sebesar 772.421 ton, sedangkan produksi beras tertinggi terjadi pada tahun 2018 sebesar 1.409 .855 ton. Hal tersebut juga diikuti oleh perkembangan konsumsi beras di NTB. Tingkat konsumsi beras terendah terjadi pada tahun 2013 sebesar 504.240 ton/tahun, sedangkan tingkat konsumsi beras tertinggi terjadi pada tahun 2018 sebesar 586.601 ton/tahun. Perbandingan jumlah produksi beras dan tingkat konsumsi beras di NTB menunjukkan adanya surplus produksi sebesar 556.194 ton. (2) Metode peramalan terbaik yang dapat digunakan untuk memproyeksikan produksi beras di Nusa Tenggara Barat tahun 2019-2023 adalah metode Trend Least Square karena mempunyai nilai MAPE terkecil, sedangkan metode peramalan terbaik untuk memproyeksikan konsumsi beras di NTB tahun 2019-2023 adalah metode Holt's Double Exponential Smoothing karena mempunyai nilai MAPE terkecil. (3) Produksi beras diproyeksikan sebanyak 1.425.916 ton pada tahun 2019 dan sebanyak 1.602 .890 ton pada tahun 2023 dengan peningkatan sebesar 22.122 ton per tahun. Konsumsi beras diproyeksikan sebanyak 599.346 ton/tahun pada tahun 2019 dan sebanyak 639.755 ton/tahun pada tahun 2023. Produksi beras dalam 5 tahun kedepan mengalami surplus diatas konsumsi sebesar 686.889 ton per tahun.
\end{abstract}

Kata Kunci: Proyeksi, Produksi dan Konsumsi Beras 


\begin{abstract}
This research aims to: (a) analyze the development of rice production and consumption in West Nusa Tenggara; (b) analyze forecasting method to project rice production and consumption in West Nusa Tenggara; and (c) projecting rice production and consumption in West Nusa Tenggara. This research used a descriptive method with analysis unit of West Nusa Tenggara Province. The type of data used are quantitative and qualitative with secondary data sources. Data analysis used included the method of descriptive, Holt's Double Exponential Smoothing method, Trend Least Square method and Mean Absolute Percentage Error (MAPE) method. The results showed that: (1) the development of rice production in West Nusa Tenggara in the past 14 years (2005-2018) experienced fluctuations, but generally increased. The lowest rice production in NTB occurred in 2005 at 772.421 tons, while the highest rice production occurred in 2018 at 1.409.855 tons. This was also followed by developments in rice consumption in NTB. The lowest rice consumption occurred in 2013 at 504.240 tons per year, while the highest rice consumption occurred in 2018 at 586.601 tons per year. Comparison of the amount of rice production and consumption in NTB shows a rice production surplus of 556.194 tons. (2) The best forecasting method that can be used for projecting rice production and consumption in NTB for 2019-2023 is the Trend Least Square method because it has the smallest MAPE value, while the best forecasting method fo projecting rice consumption in 2019-2023 is the Double Exponential Smoothing by Holt method because it has the smallest MAPE value. (3) Rice production is projected at 1.425.916 tons in 2019 and as many as 1.602 .890 tons in 2023 with an increase of 22.122 tons per year. Rice consumption is projected at 599.755 tons per year ini 2019 and as much as 639.755 tons per year ini 2023. Rice production in the next 5 years experiences a surplus above consumption of 686.889 tons per year.
\end{abstract}

Keywords: Projection, Rice Production and Consumption 


\section{PENDAHULUAN}

Kebutuhan terhadap pangan adalah salah satu kebutuhan pokok manusia. Ketika populasi penduduk semakin berkembang dengan laju yang cukup tinggi, kebutuhan terhadap pangan harus dipenuhi melalui proses budidaya pertanian. Menurut Sawit (2000), beras harus dipandang sebagai barang kuasi publik, yang tidak saja berfungsi sebagai barang privat tetapi juga barang publik. Banyak kepentingan publik dihasilkan oleh beras, dan beras berperan penting dalam ketahanan pangan, stabilitas ekonomi, dan lapangan kerja. Nusa Tenggara Barat merupakan salah satu daerah super fokus sentra produksi beras nasional yang ditetapkan oleh pemerintah sejak tahun 2006. Seiring dengan pertambahan jumlah dan kualitas hidup (standard of living) penduduk Indonesia khususnya NTB, maka permintaan akan pangan bakal terus meningkat dari tahun ke tahun. Selain secara kuantitas permintaan akan bahan pangan di Indonesia terus meningkat, ketergantungan mayoritas penduduk Indonesia khususnya NTB yang sangat bergantung pada beras sebagai sumber karbohidrat juga menjadi masalah tersendiri yang cukup rumit. Pola perkembangan produksi beras dan tingkat konsumsi beras di Nusa Tenggara Barat mengalami fluktuasi namun secara umum mengalami peningkatan. Oleh karena itu, dengan berfluktuasinya pola perkembangan produksi dan konsumsi beras di NTB, perlu untuk diketahui produksi dan tingkat konsumsi beras di NTB pada beberapa tahun kedepan, apakah produksi beras pada masa yang akan datang mampu untuk mencukupi kebutuhan konsumsi beras di NTB atau tidak. Selain itu, kurangnya informasi mengenai perkiraan jumlah produksi dan konsumsi beras di NTB juga menjadi salah satu alasan penelitian ini dilakukan. Salah satu upaya yang dapat dilakukan untuk mengantisipasi hal tersebut yaitu dengan melakukan analisis mengenai proyeksi produksi dan konsumsi beras di Nusa Tenggara Barat pada masa yang akan datang, sehingga dapat diperkirakan berapa jumlah pasokan beras yang dibutuhkan. 


\section{METODOLOGI PENELITIAN}

Metode yang digunakan dalam penelitian ini adalah metode deskriptif. Metode deskriptif merupakan metode penelitian yang bertujuan untuk memecahkan masalah yang ada sekarang dengan cara mengumpulkan data, menyusun, menganalisa, menginterpretasikan dan menarik kesimpulan. Unit analisis dalam penelitian ini adalah produksi dan konsumsi beras di wilayah Provinsi Nusa Tenggara Barat yang merupakan Lumbung Padi Nasional. Jenis data yang digunakan dalam penelitian ini adalah data kuantitatif dan data kualitatif. Data kuantitatif terdiri dari data produksi dan konsumsi beras. Data kualitatif adalah data yang dikumpulkan dari hasil pengkajian terhadap hasil penelitian terdahulu, serta fenomena-fenomena terkait di wilayah penelitian. Sumber data yang digunakan dalam penelitian ini adalah data sekunder, yaitu data yang diperoleh dari literatur-literatur, dokumen-dokumen, situs-situs, informasi yang terkait, Badan Pusat Statistik Provinsi NTB, Dinas Pertanian Provinsi NTB, dan Dinas Ketahanan Pangan Provinsi NTB. Variabel-variabel yang diteliti dan cara pengukurannya antara lain: (1) produksi beras selama satu tahun di Nusa Tenggara Barat yang dinyatakan dalam satuan ton; (2) Konsumsi beras selama satu tahun di Nusa Tenggara Barat yang dinyatakan dalam satuan ton/tahun; (3) Penduduk di Nusa Tenggara Barat yang dinyatakan dalam satuan jiwa; dan (4) waktu yaitu lama peramalan yang dilakukan yang dinyatakan dalam skor.

\section{Analisis Data}

Alat analisis data yang digunakan untuk menganalisis perkembangan produksi dan konsumsi beras di Nusa Tenggara Barat adalah metode deskriptif. Sedangkan untuk menganalisis metode peramalan yang tepat dan memproyeksikan produksi dan konsumsi beras di Nusa Tenggara Barat Tahun 2019-2023 menggunakan metode Double Exponential Smoothing oleh Holt dan metode Trend Least Square, sedangkan metode yang digunakan untuk mengetahui tingkat kesalahan terkecilnya adalah metode Mean Absolute Percentage Error (MAPE).

\section{a) Metode Double Exponential Smoothing oleh Holt}

Menurut Markidakis (1993), metode pemulusan eksponensial linier dari Holt pada prinsipnya serupa dengan Brown kecuali bahwa Holt tidak menggunakan rumus pemulusan berganda secara langsung. Sebagai gantinya, Holt memutuskan nilai trend dengan parameter yang berbeda dari dua parameter yang digunakan pada deret yang asli.

Ramalan dari pemulusan eksponensial linier Holt didapat dengan menggunakan dua konstanta pemulusan (dengan nilai antara 0 dan 1) dan tiga persamaan, yaitu: 


$$
\begin{aligned}
& s^{\prime} t=\alpha X_{t}+(1-\alpha)\left(s_{t-1}^{\prime}+b_{t-1}\right) \\
& b_{t}=\beta\left(s_{t}-s_{t-1}\right)+(1-\beta) b_{t-1} \\
& F_{t}+m=s_{t}+b_{t} m
\end{aligned}
$$

Inisialisasi:

$s_{1}=x_{1}$

$b_{1}=x_{2}-x_{1}$

Dimana:
$x_{t}$
: Data pada periode $\mathrm{t}$
$s_{t}^{\prime} \quad$ : Nilai single exponential smoothing
$b_{t} \quad: \quad$ Nilai trend pada periode ke-t
$\alpha, \beta \quad$ : Parameter $\mathrm{m}$ periode yang akan diramalkan
$F_{t}+m \quad$ : Ramalan $\mathrm{m}$ periode yang akan diramalkan
$\mathrm{m}$ : Jumlah periode ke muka yang akan diramalkan

\section{b) Metode Trend Least Square}

Menurut Sugiarto dan Harijono (2000), aplikasi metode least square (jumlah kuadrat terkecil) untuk data deret waktu ditujukan untuk melihat trend dari data deret waktu. Model linier deret waktu ditentukan sebagai berikut:

$$
\hat{Y}_{t}=a+b X
$$

$$
\text { dimana: } a=\frac{\sum Y}{n} \quad \text { dan } \quad b=\frac{\sum X Y}{\sum X^{2}}
$$

Keterangan:

$\hat{Y}_{t}$ : nilai ramalan pada periode waktu ke-t

a : bilangan konstan

b : slope atau koefisien kecondongan garis trend

$X$ : mewakili waktu

$Y \quad$ : data aktual

Untuk memberikan nilai skor pada $\mathrm{X}$, dilakukan pembagian menjadi dua kelompok. Untuk data yang jumlahnya:

- Genap, maka skor nilai X nya adalah .....,-5, -3, -1, 1, 3, 5, ...

- Ganjil, maka skor nilai $X$ nya adalah ......, $-2,-1,0,1,2, \ldots .$.

\section{c) Mean Absolute Percentage Error (MAPE)}

Suatu metode peramalan dikatakan bagus apabila metode tersebut berhasil meramalkan sesuatu dengan tepat. Menurut Bowerman (1987) dalam Sungkawa (2011), dalam semua situasi peramalan mengandung derajat ketidakpastian. Kita mengenali fakta ini dengan memasukkan unsur kesalahan (error) dalam perumusan sebuah peramalan deret waktu. Sumber penyimpangan dalam peramalan bukan hanya disebabkan oleh unsur error, tetapi ketidakmampuan suatu model peramalan mengenali unsur yang lain dalam deret data juga mempengaruhi besarnya penyimpangan dalam peramalan. Terdapat beberapa metode yang digunakan untuk ukuran-ukuran ketepatan relatif yang sering digunakan untuk mengetahui ketapatan suatu metode peramalan dalam memodelkan data deret waktu, yaitu nilai Mean Absolute Percentage Error (MAPE), Mean Squared Deviation (MSD), dan Mean Absolute Error (MAD). MAPE merupakan ukuran ketepatan relatif yang 
digunakan untuk mengetahui persentase penyimpangan hasil peramalan, dengan persamaan sebagai berikut:

$$
M A P E=\sum_{t=1}^{n} \frac{P E t}{n}
$$

Galat persentase (Percentage Error)

$$
P E=\left(\frac{X t-F t}{X t}\right) \times 100
$$

Suatu model mempunyai kinerja sangat bagus jika nilai MAPE berada di bawah $10 \%$ dan mempunyai kinerja yang bagus jika nilai MAPE berada diantara $10 \%$ dan $20 \%$.

\section{HASIL DAN PEMBAHASAN}

\section{Perkembangan Produksi dan Konsumsi Beras di Nusa Tenggara Barat}

\section{Perkembangan Produksi Beras di Nusa Tenggara Barat}

Perkembangan jumlah penduduk di NTB yang semakin meningkat setiap tahunnya menuntut petani untuk dapat meningkatkan produksi beras sehingga mampu memenuhi kebutuhan beras.

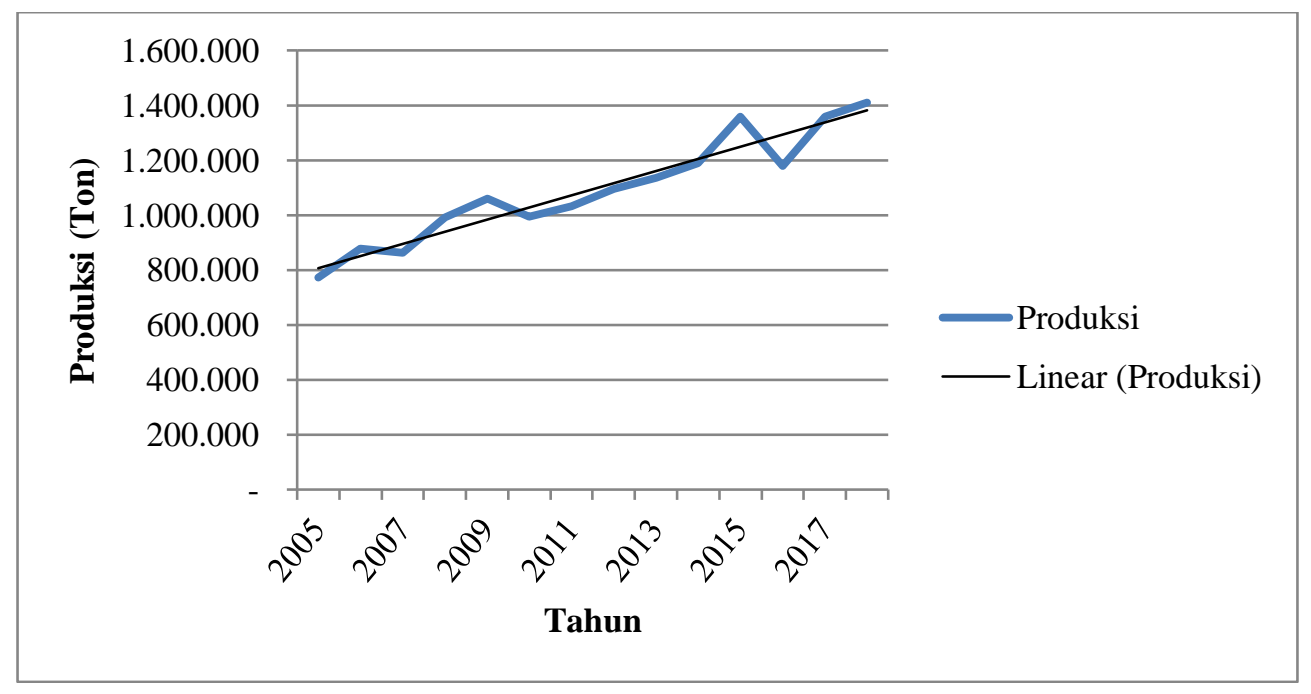

Gambar 1. Plot Data Produksi Beras NTB, 2005-2018

Perkembangan produksi beras di Nusa Tenggara Barat dapat ditunjukkan pada Gambar 1 bahwa produksi beras dari tahun ke tahun berfluktuatif, namun secara umum mengalami peningkatan. Plot data perkembangan produksi beras di NTB tahun 2005 - 2018 disajikan pada Tabel 1 berikut. 
Tabel 1. Produksi Beras di Nusa Tenggar Barat Tahun 2005 - 2018

\begin{tabular}{ccc}
\hline Tahun & $\begin{array}{c}\text { Produksi } \\
(\text { Ton) }\end{array}$ & $\begin{array}{c}\text { Persentase Produksi } \\
(\%)\end{array}$ \\
\hline 2005 & 772.421 & - \\
2006 & 877.845 & 13,65 \\
2007 & 862.849 & $(1,71)$ \\
2008 & 990.852 & 14,83 \\
2009 & 1.059 .380 & 6,92 \\
2010 & 995.036 & $(6,07)$ \\
2011 & 1.031 .831 & 3,70 \\
2012 & 1.095 .082 & 6,13 \\
2013 & 1.136 .242 & 3,76 \\
2014 & 1.190 .042 & 4,73 \\
2015 & 1.359 .136 & 14,21 \\
2016 & 1.177 .944 & $(13,33)$ \\
2017 & 1.358 .760 & 15,35 \\
2018 & 1.409 .855 & 3,76 \\
\hline Rerata & 1.094 .091 & \\
\hline
\end{tabular}

Tabel 1 menunjukkan bahwa produksi beras di NTB dari tahun 2006 mengalami peningkatan dari tahun sebelumnya yaitu sebesar $13,65 \%$. Namun pada tahun berikutnya yaitu tahun 2007, NTB mengalami penurunan produksi beras dari tahun sebelumnya sebesar $1,71 \%$. Produksi beras terendah di NTB terjadi pada tahun 2005 yaitu sebesar 772.421 ton. Sedangkan produksi beras tertinggi terjadi pada tahun 2018 sebesar 1.409 .855 ton.

\section{Perkembangan Konsumsi Beras di Nusa Tenggara Barat}

Provinsi Nusa Tenggara Barat merupakan provinsi yang paling banyak mengkonsumsi beras, yakni mencapai $118,1 \mathrm{~kg} / \mathrm{kapita} / \mathrm{tahun}$ berdasarkan hasil Survei Sosial Ekonomi Nasional (Susenas) BPS pada tahun 2011. Jumlah konsumsi ini berada di atas rata-rata nasional yaitu $110 \mathrm{~kg} / \mathrm{kapita} /$ tahun.

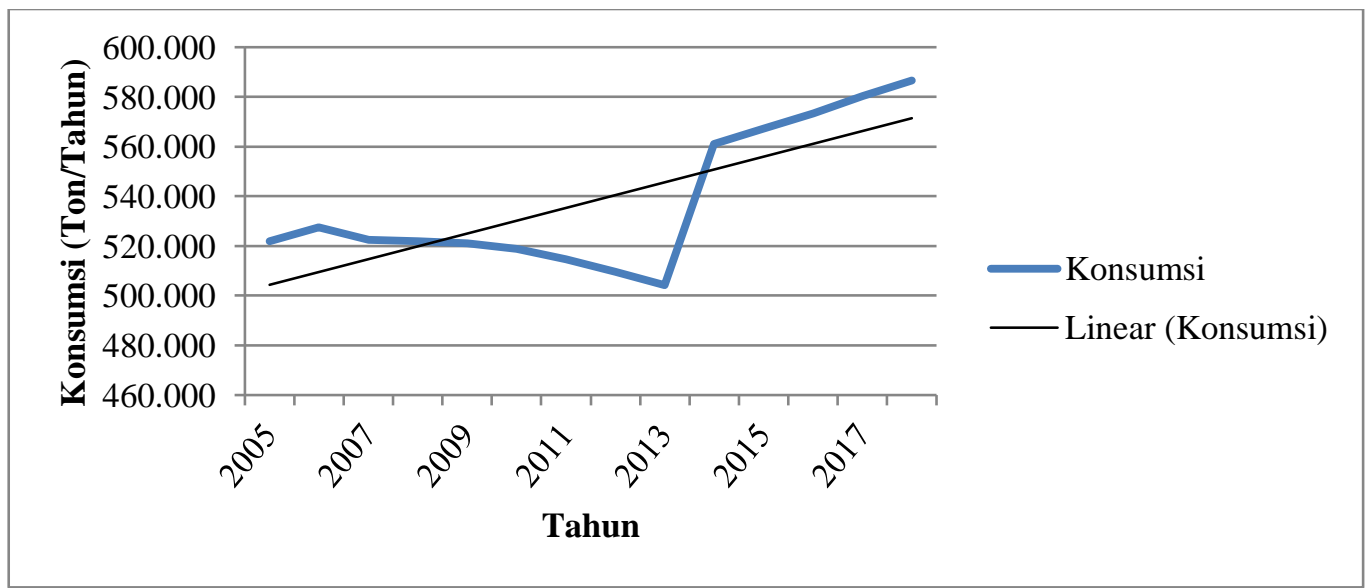

Sumber: Analisis Data Sekunder (2019)

Gambar 2. Plot Data Konsumsi Beras NTB, 2005-2018 
Gambar 2 menunjukkan bahwa tingkat konsumsi beras di Nusa Tenggara Barat setiap tahunnya mengalami fluktuasi, namun apabila dilihat dari garis trend, secara umum konsumsi beras di NTB mengalami peningkatan. Tingkat konsumsi beras di NTB disajikan pada Tabel 2.

Tabel 2. Konsumsi Beras di Nusa Tenggara Barat Tahun 2005 - 2018

\begin{tabular}{cccccc}
\hline Tahun & $\begin{array}{c}\text { Konsumsi } \\
\text { Per Kapita }\end{array}$ & $\begin{array}{c}\text { Jumlah } \\
\text { Penduduk } \\
\text { NTB }\end{array}$ & $\begin{array}{c}\text { Persentase } \\
\text { Jumlah } \\
\text { Penduduk } \\
\text { NTB } \\
(\%)\end{array}$ & $\begin{array}{c}\text { Konsumsi } \\
\text { Per Tahun }\end{array}$ & $\begin{array}{c}\text { Persentase } \\
\text { Konsumsi/Thn }\end{array}$ \\
\hline \hline 2005 & 126,0 & 4.143 .292 & - & 522.055 & $(\%)$ \\
2006 & 123,9 & 4.257 .306 & 2,75 & 527.480 & 1,04 \\
2007 & 121,7 & 4.292 .491 & 0,83 & 522.396 & $(0,96)$ \\
2008 & 119,6 & 4.363 .756 & 1,66 & 521.905 & $(0,09)$ \\
2009 & 117,5 & 4.434 .012 & 1,61 & 520.996 & $(0,17)$ \\
2010 & 115,3 & 4.500 .212 & 1,49 & 518.874 & $(0,41)$ \\
2011 & 113,2 & 4.545 .650 & 1,01 & 514.568 & $(0,83)$ \\
2012 & 111,1 & 4.587 .562 & 0,92 & 509.678 & $(0,95)$ \\
2013 & 108,9 & 4.630 .302 & 0,93 & 504.240 & $(1,07)$ \\
2014 & 117,5 & 4.773 .795 & 3,10 & 560.921 & 11,24 \\
2015 & 117,3 & 4.835 .577 & 1,29 & 567.213 & 1,12 \\
2016 & 117,1 & 4.896 .162 & 1,25 & 573.341 & 1,08 \\
2017 & 117,1 & 4.955 .578 & 1,21 & 580.298 & 1,21 \\
2018 & 117,0 & 5.013 .687 & 1,17 & 586.601 & 1,09 \\
\hline
\end{tabular}

Sumber: Analisis Data Sekunder (2019)

Tabel 2 menunjukkan tingkat konsumsi beras di Nusa Tenggara Barat. Pada tahun 2006 tingkat konsumsi beras meningkat sebesar 1,04\% dari tahun sebelumnya. Penurunan tingkat konsumsi beras terjadi pada tahun 2007 hingga 2013 masing-masing sebesar 0,96\%; 0,09\%; 0,17\%; 0,41\%; 0,83\%; 0,95\%; dan 1,07\%; hingga akhirnya pada tahun 2014 tingkat konsumsi beras meningkat tajam dengan persentase peningkatan sebesar $11,24 \%$. Tingkat konsumsi beras terendah terjadi pada tahun 2013 sebesar 504.240 ton/tahun, sedangkan tingkat konsumsi beras tertinggi terjadi pada tahun 2018 sebesar 586.601 ton/tahun.

\section{Perbandingan Produksi dan Konsumsi Beras di Nusa Tenggara Barat}

Gambar 3 menunjukkan perbandingan produksi dan konsumsi beras di Nusa Tenggara Barat dalam kurun waktu 14 tahun terakhir (2005-2018). Grafik diatas menunjukkan bahwa Nusa Tenggara Barat mengalami surplus produksi atau kelebihan produksi beras. Kelebihan produksi beras di Nusa Tenggara Barat tahun 2005-2018 dapat disajikan pada Tabel 3. 


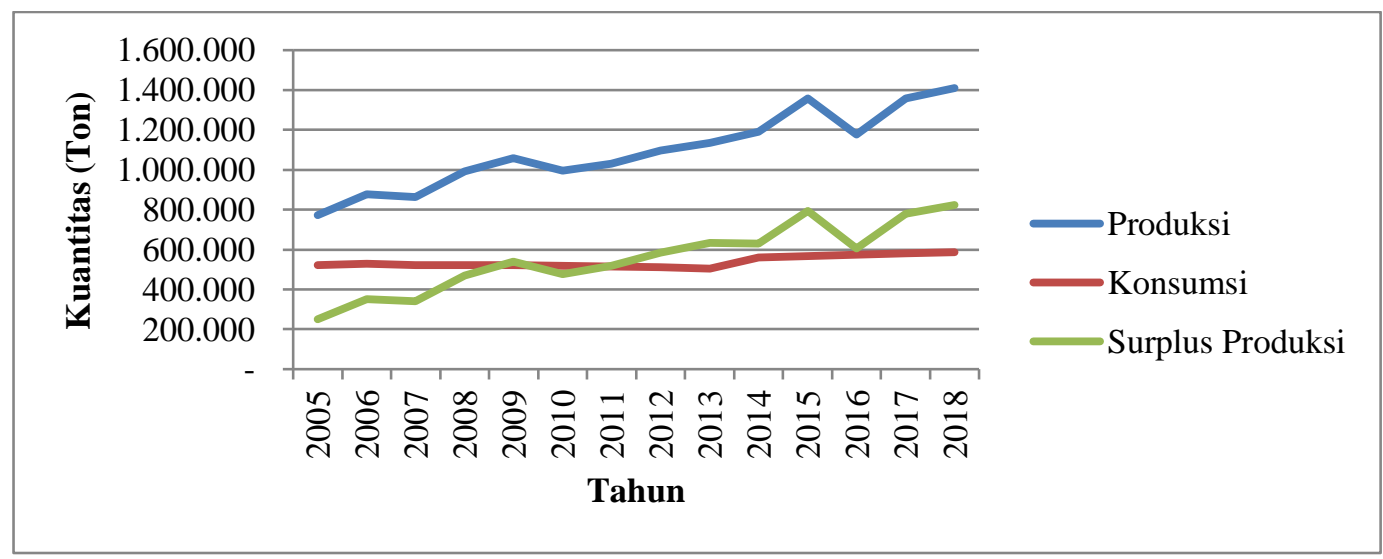

Sumber: Analisis Data Sekunder (2019)

Gambar 3. Perbandingan Produksi dan Konsumsi Beras di NTB, Tahun 2005 - 2018

Tabel 3. Produksi, Konsumsi dan Surplus Beras di NTB, 2005-2018

\begin{tabular}{cccccc}
\hline Tahun & $\begin{array}{c}\text { Produksi } \\
(\text { Ton })\end{array}$ & $\begin{array}{c}\text { Persentase } \\
\text { Produksi } \\
(\%)\end{array}$ & $\begin{array}{c}\text { Konsumsi } \\
(\text { Ton/Tahun })\end{array}$ & $\begin{array}{c}\text { Persentase } \\
\text { Konsumsi } \\
(\%)\end{array}$ & $\begin{array}{c}\text { Surplus Produksi } \\
(\text { Ton) }\end{array}$ \\
\hline 2005 & 772.421 & - & 522.055 & - & 250.366 \\
2006 & 877.845 & 13,65 & 527.480 & 1,04 & 350.365 \\
2007 & 862.849 & $(1,71)$ & 522.396 & $(0,96)$ & 340.453 \\
2008 & 990.852 & 14,83 & 521.905 & $(0,09)$ & 468.947 \\
2009 & 1.059 .380 & 6,92 & 520.996 & $(0,17)$ & 538.384 \\
2010 & 995.036 & $(6,07)$ & 518.874 & $(0,41)$ & 476.162 \\
2011 & 1.031 .831 & 3,70 & 514.568 & $(0,83)$ & 517.263 \\
2012 & 1.095 .082 & 6,13 & 509.678 & $(0,95)$ & 585.404 \\
2013 & 1.136 .242 & 3,76 & 504.240 & $(1,07)$ & 632.002 \\
2014 & 1.190 .042 & 4,73 & 560.921 & 11,24 & 629.121 \\
2015 & 1.359 .136 & 14,21 & 567.213 & 1,12 & 791.923 \\
2016 & 1.177 .944 & $(13,33)$ & 573.341 & 1,08 & 604.603 \\
2017 & 1.358 .760 & 15,35 & 580.298 & 1,21 & 778.462 \\
2018 & 1.409 .855 & 3,76 & 586.601 & 1,09 & 823.254 \\
\hline
\end{tabular}

Sumber: Badan Ketahanan Pangan Provinsi NTB (2018)

Tabel 3 menunjukkan adanya surplus beras di Nusa Tenggara Barat. Hal ini ditunjukkan oleh rata-rata surplus beras sebesar 556.195 ton. berdasarkan angka produksi dan konsumsi beras di NTB menunjukkan trend yang terus meningkat dengan angka surplus beras yang juga meningkat. Data ini menunjukkan bahwa ketahanan pangan dari aspek ketersediaan beras cukup aman. Menurut Mashur (2016), Provinsi NTB telah mampu membantu beberapa provinsi lain di Indonesia terutama provinsi tetangga seperti Bali, NTT, Kaltim, bahkan petani NTB melalui Kontak Tani Nelayan Andalan (KTNA) Nasional telah menyumbang gabahnya kepada petani miskin di Afrika Selatan. 


\section{Metode Peramalan Kuantitatif untuk Memproyeksikan Produksi dan Konsumsi Beras di Nusa Tenggara Barat}

\section{Identifikas Pola Data Produksi dan Konsumsi Beras di Nusa Tenggara Barat}

Pola data yang diperoleh dilakukan menggunakan program Microsoft Excel untuk mengetahui plot data dari produksi dan tingkat konsumsi beras. Grafik plot time series produksi dan konsumsi beras di Nusa Tenggara Barat disajikan pada Gambar 1 dan Gambar 2.

Gambar 1 dan Gambar 2 masing-masing menunjukkan pola data trend, namun secara umum mengalami peningkatan. Pola data trend terbentuk jika terdapat kenaikan atau penurunan sekuler jangka panjang dalam data. Berdasarkan analisis pola data tersebut, maka metode peramalan yang sesuai dengan pola data produksi dan konsumsi beras antara lain Double Exponential Smoothing dari Holt dan Metode Trend Least Square. Produksi dan konsumsi beras selanjutnya akan dianalisis menggunakan kedua metode tersebut dan akan diperoleh nilai kesalahan terkecil melalui nilai MAPE. Metode peramalan yang memiliki nilai MAPE terkecil yaitu dibawah $10 \%$ mempunyai kinerja yang sangat bagus, sedangkan metode peramalan yang memiliki nilai MAPE diantara 10\% dan 20\% mempunyai kinerja yang bagus.

2. Metode Peramalan Kuantitatif Produksi dan Konsumsi Beras di NTB

a) Metode Double Exponential Smoothing oleh Holt

1) Proyeksi Produksi Beras di Nusa Tenggara Barat, 2005-2018

Untuk memproyeksikan produksi beras di Nusa Tenggara Barat selama 5 tahun mendatang dengan menggunakan Metode Double Exponential Smoothing oleh Holt, digunakan dua parameter yaitu a dan $\beta$. Diperoleh nilai $\alpha$ dan $\beta$ masing-masing sebesar 0,30 dan 0,66 . Nilai $\alpha$ dan $\beta$ diperoleh menggunakan data solver pada program Microsoft Excel. Perolehan nilai MAPE untuk produksi beras dengan metode Holt sebesar $7,19 \%$ (terkecil). Nilai MAPE sebesar 7,19\% menunjukkan bahwa kemampuan peramalan dengan metode ini memiliki tingkat akurasi yang sangat baik. Hasil perbandingan antara data aktual dan data hasil peramalan menggunakan Holt Double Exponential Smoothing dapat dilihat pada Gambar 4.

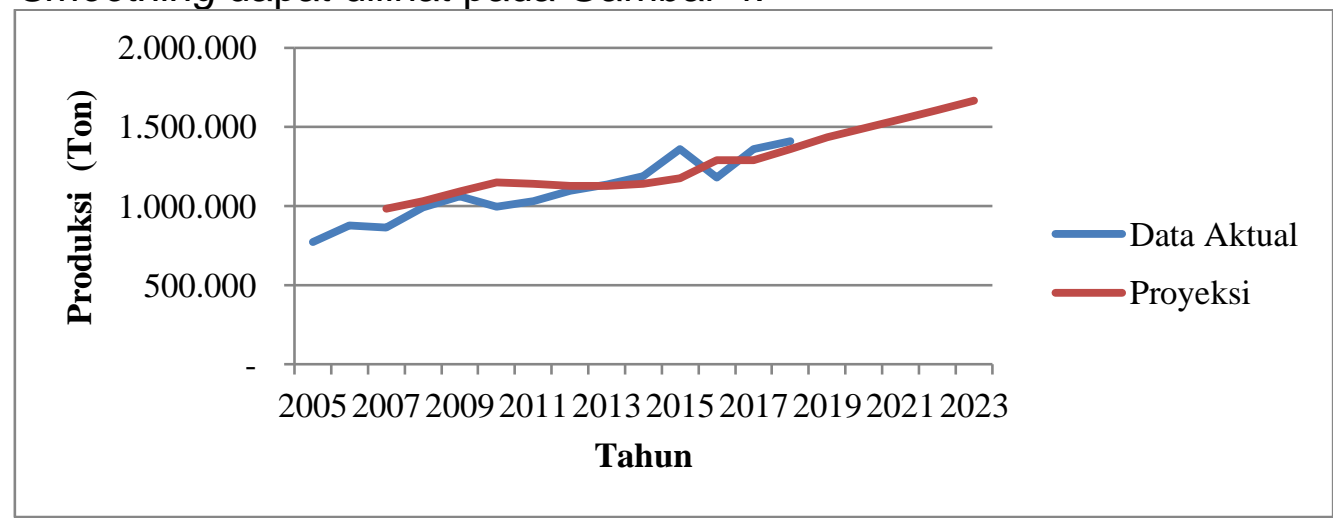

Sumber: Analisis Data Sekunder (2019)

Gambar 4. Perbandingan Data Aktual dengan Perkiraan Produksi Beras di NTB dengan Metode Holt 
Gambar 4 menunjukkan perbandingan data aktual produksi beras dengan data perkiraan produksi beras di Nusa Tenggara Barat selama 5 tahun mendatang. Grafik di atas menunjukkan bahwa proyeksi produksi beras tahun 2019-2023 mengalami peningkatan produksi.

\section{2) Proyeksi Konsumsi Beras di Nusa Tenggara Barat, 2005-2018}

Untuk memproyeksi konsumsi beras di Nusa Tenggara Barat selama 5 tahun mendatang dengan menggunakan Metode Double Exponential Smoothing oleh Holt, digunakan dua parameter yaitu a dan $\beta$. Diperoleh nilai $\alpha$ dan $\beta$ masing-masing sebesar 0,62 dan 0,32 . Nilai $\alpha$ dan $\beta$ diperoleh menggunakan data solver pada program Microsoft Excel. Perolehan nilai MAPE untuk proyeksi konsumsi beras di NTB dengan metode Holt sebesar $2,11 \%$. Hal ini menunjukkan bahwa kemampuan peramalan dengan metode ini memiliki tingkat akurasi yang sangat baik. Hasil perbandingan antara data aktual dan data hasil peramalan menggunakan Holt Double Exponential Smoothing dapat dilihat pada Gambar 5.

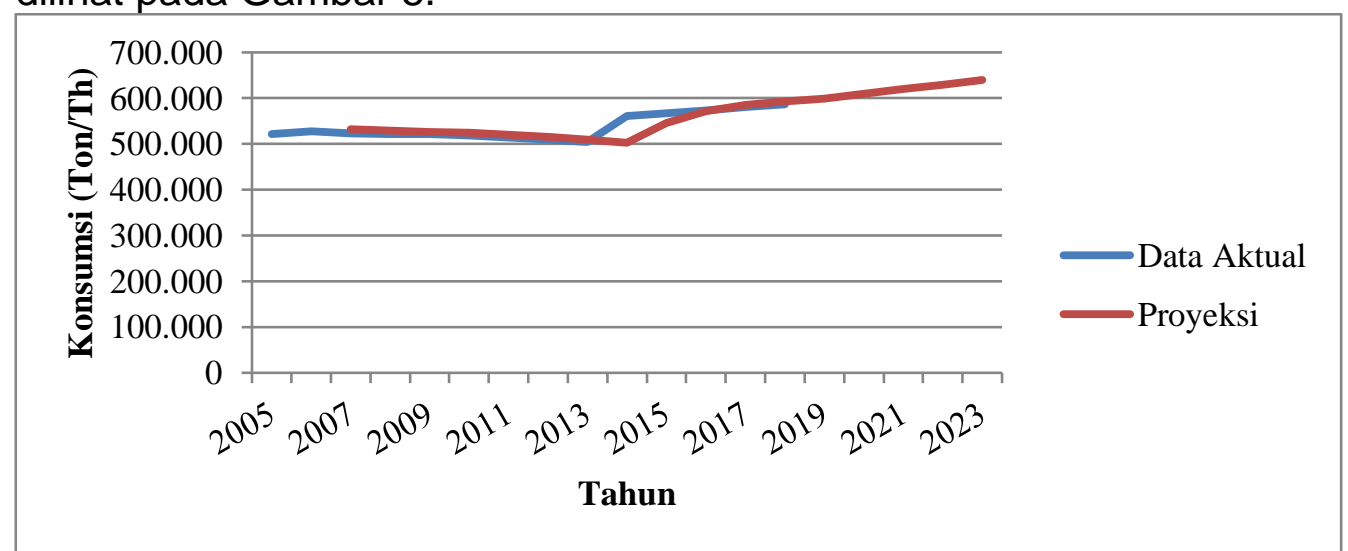

Sumber: Analisis Data Sekunder (2019)

Gambar 5. Perbandingan Data Aktual dengan Perkiraan Konsumsi Beras di NTB dengan Metode Holt

Gambar 5 menunjukkan perbandingan data aktual konsumsi beras dengan data perkiraan produksi beras di Nusa Tenggara Barat selama 5 tahun mendatang. Grafik diatas menunjukkan bahwa proyeksi konsumsi beras untuk tahun 2019-2023 mengalami fluktuasi tetapi jika dilihat dari garis trend, proyeksi konsumsi beras secara umum mengalami peningkatan. Proyeksi konsumsi beras di Nusa Tenggara Barat tahun 2019-2023 mengalami peningkatan sejalan dengan meningkatnya proyeksi produksi beras.

\section{b) Metode Trend Least Square}

\section{1) Proyeksi Produksi Beras di Nusa Tenggara Barat, 2019-2023}

Untuk memproyeksikan produksi beras di Nusa Tenggara Barat tahun 2019-2023 juga digunakan Metode Trend Least Square. Metode tersebut sama dengan regresi linier sederhana dengan periode waktu (X) sebagai variabel bebas. Menggunakan teknis analisis sebagaimana 
yang telah dijelaskan diperoleh persamaan yaitu $\hat{Y}=1.094 .091+$ 22.122 X. Artinya produksi beras di Nusa Tenggara Barat mengalami peningkatan sebesar 22.122 ton per tahun. Dengan menggunakan persamaan tersebut, dapat diproyeksikan produksi beras di Nusa Tenggara Barat pada tahun 2019-2023. Perolehan nilai MAPE untuk proyeksi beras di Nusa Tenggara Barat untuk Tahun 2019-2023 dengan metode TLS sebesar 4\%. Hal ini menunjukkan bahwa kemampuan peramalan dengan metode ini memiliki tingkat akurasi yang sangat baik. Hasil perbandingan antara data aktual dan data hasil peramalan menggunakan Trend Least Square dapat dilihat pada Gambar 6.

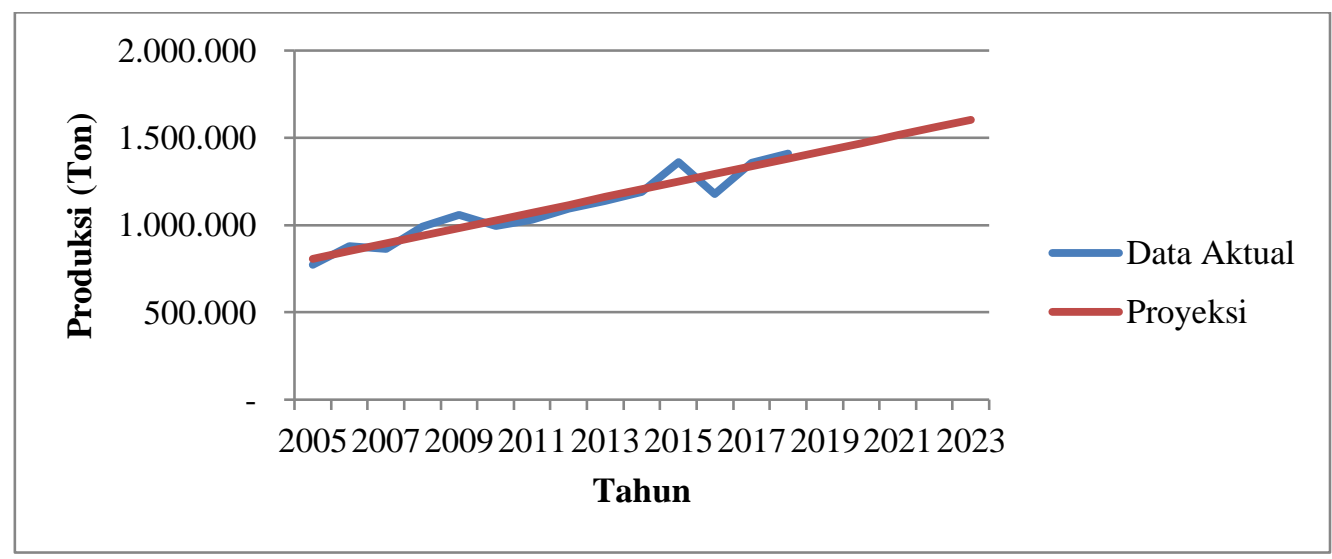

Sumber: Analisis Data Sekunder (2019)

Gambar 6. Perbandingan Data Aktual dengan Perkiraan Produksi Beras NTB dengan Metode TLS

Gambar 6 menunjukkan perbandingan data aktual produksi beras dengan data perkiraan produksi beras di Nusa Tenggara Barat selama 5 tahun mendatang. Grafik diatas menunjukkan bahwa proyeksi produksi beras untuk tahun 2019-2023 mengalami peningkatan produksi.

\section{2) Proyeksi Konsumsi Beras di Nusa Tenggara Barat, 2019-2023}

Untuk memproyeksikan konsumsi beras di Nusa Tenggara Barat selama 5 tahun mendatang juga digunakan Metode Trend Least Square. Metode tersebut sama dengan regresi linier sederhana dengan periode waktu $(X)$ sebagai variabel bebas. Menggunakan teknis analisis sebagaimana yang telah dijelaskan diperoleh persamaan yaitu $\hat{Y}=537.839+2.579 \mathrm{X}$. Artinya konsumsi beras di Nusa Tenggara Barat mengalami peningkatan sebesar 2.579 ton per tahun. Dengan menggunakan persamaan tersebut, dapat diproyeksikan konsumsi beras di Nusa Tenggara Barat pada tahun 2019-2023. Perolehan nilai MAPE untuk proyeksi beras di Nusa Tenggara Barat untuk Tahun 2019-2023 dengan metode Holt sebesar 3\%. Hal ini menunjukkan bahwa kemampuan peramalan dengan metode ini memiliki tingkat akurasi yang sangat baik. Hasil perbandingan antara data aktual dan 
data hasil peramalan menggunakan Trend Least Square dapat dilihat pada Gambar 7.

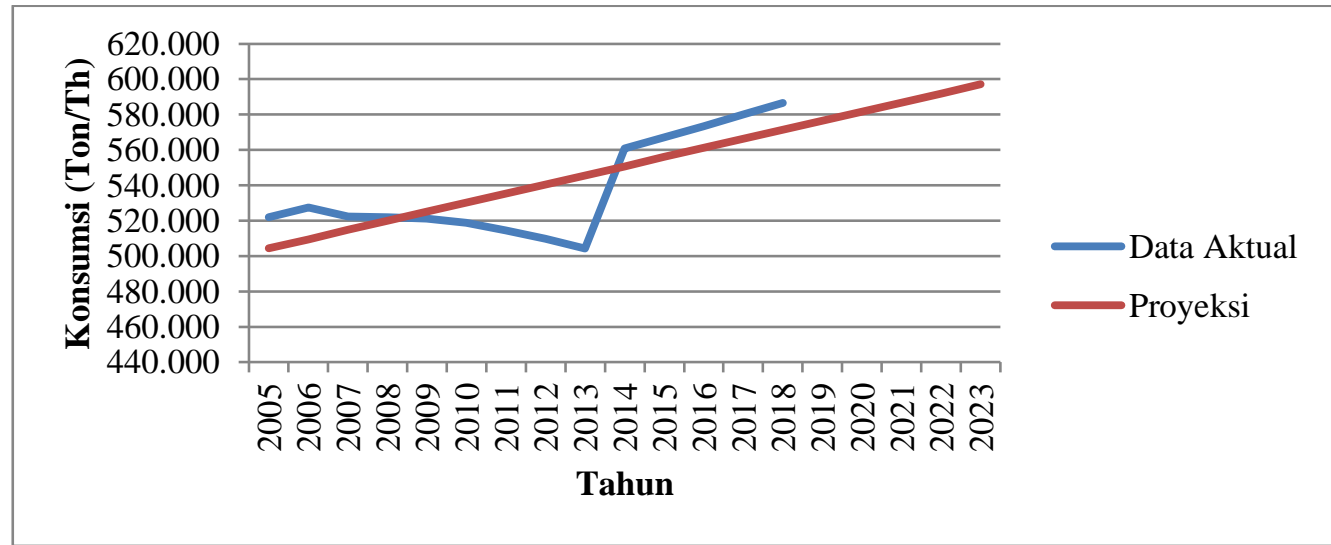

Sumber: Analisis Data Sekunder (2019)

Gambar 7. Perbandingan Data Aktual dengan Perkiraan Konsumsi Beras NTB dengan Metode TLS

Gambar 7 menunjukkan perbandingan data aktual konsumsi beras dengan data perkiraan konsumsi beras di Nusa Tenggara Barat selama 5 tahun mendatang. Grafik diatas menunjukkan bahwa proyeksi konsumsi beras untuk tahun 2019-2023 mengalami fluktuasi namun apabila dilihat dari garis trend proyeksi konsumsi beras di NTB mengalami peningkatan.

\section{c) Metode Peramalan Terbaik untuk Memproyeksikan Produksi dan Konsumsi Beras di Nusa Tenggara Barat}

Pemilihan metode terbaik adalah dengan melihat kesalahan terkecil yaitu nilai MAPE yang diperoleh. MAPE merupakan ukuran ketepatan relatif yang digunakan untuk mengetahui persentase penyimpangan hasil peramalan. Berikut merupakan niali MAPE yang diperoleh masing-masing metode peramalan yang disajikan pada Tabel 4 .

Tabel 4. Nilai MAPE yang Diperoleh dari Masing-masing Metode

Peramalan pada Produksi dan Konsumsi Beras di Nusa Tenggara Barat

\begin{tabular}{lrr}
\hline \multicolumn{1}{c}{ Metode Peramalan } & Produksi Beras & Konsumsi Beras \\
\hline Holt Double Exponential & $7,19 \%$ & $2,11 \%$ \\
Smoothing & $4 \%$ & $3 \%$ \\
Trend Least Square & &
\end{tabular}

Sumber: Analisis Data Sekunder (2019)

Tabel 4 menunjukkan bahwa bahwa untuk produksi beras metode Trend Least Square merupakan metode terbaik karena memiliki nilai MAPE terkecil sebesar $4 \%$. Sedangkan untuk konsumsi beras metode Holt Double Exponential Smoothing merupakan metode terbaik karena memiliki nilai MAPE terkecil sebesar 2,11\%. Semakin kecil nilai MAPE yang diperoleh pada suatu metode peramalan, maka semakin mendekati 
nilai aktualnya. Penggunaan metode tersebut menggunakan deret waktu selama kurun waktu 14 tahun terakhir yaitu dari tahun 2005 hingga 2018. Penelitian ini dilakukan dengan mengambil data produksi dan konsumsi beras di Nusa Tenggara Barat. Biaya yang dikeluarkan dalam mengambil metode Holt Double Exponential Smoothing dan Trend Least Square tidak mahal dan tidak membutuhkan waktu yang lama.

\section{Proyeksi Produksi dan Konsumsi Beras di Nusa Tenggara Barat, Tahun 2019-2023}

\section{Proyeksi Produksi Beras di Nusa Tenggara Barat}

\section{a) Proyeksi Produksi Beras di Nusa Tenggara Barat}

Metode yang digunakan dalam menganalisis data produksi Beras di Nusa Tenggara Barat adalah Trend Least Square. Metode ini digunakan karena pola data produksi aktual menunjukkan adanya unsur trend. Selain itu, TLS memiliki nilai penyimpangan terkecil. Hasil proyeksi produksi beras di Nusa Tenggara Barat untuk 5 tahun mendatang dapat disajikan pada Tabel 5.

Tabel 5. Proyeksi Produksi Beras di Nusa Tenggara Barat, 2019-2023

\begin{tabular}{cccc}
\hline Tahun & Periode & Nilai Ramalan & MAPE \\
\hline 2019 & 15 & 1.425 .916 & \\
2020 & 16 & 1.470 .160 & \\
2021 & 17 & 1.514 .403 & \\
2022 & 18 & 1.558 .646 & $4 \%$ \\
2023 & 19 & 1.602 .890 & \\
\hline \multicolumn{5}{c}{ Nilai Kesalahan }
\end{tabular}

Sumber : Analisis Data Sekunder (2019)

Tabel 5 menunjukkan hasil estimasi produksi Beras di Provinsi Nusa Tenggara Barat Tahun 2019-2023 menggunakan metode Trend Least Square. Proyeksi produksi beras selama 5 tahun mendatang mengalami peningkatan. Proyeksi produksi beras pada tahun 2019 sebesar 1.425.916 ton; pada tahun 2020 sebesar 1.470 .160 ton; pada tahun 2021 sebesar 1.514 .403 ton; pada tahun 2022 sebesar 1.558 .646 ton; dan pada tahun 2023 sebesar 1.602 .890 ton. Peningkatan nilai peramalan produksi beras di Nusa Tenggara Barat sebesar 22.122 ton per tahun. Untuk mendeteksi ketepatan dari hasil nilai ramalan yang dibandingkan dengan observasi (data aktual) untuk metode peramalan data deret waktu perlu ditentukan nilai MAPE. Nilai MAPE minimum yang dihasilkan yaitu $4 \%$, yang berarti bahwa kemampuan peramalan dengan metode ini memiliki tingkat akurasi yang baik.

\section{b) Proyeksi Tingkat Konsumsi Beras di Nusa Tenggara Barat}

Metode yang digunakan dalam menganalisis data konsumsi Beras di Nusa Tenggara Barat adalah Double Exponential Smoothing oleh Holt. Metode ini digunakan karena pola data produksi aktual menunjukkan adanya unsur musiman dan trend. Selain itu, Double Exponential 
Smoothing oleh Holt memiliki nilai penyimpangan terkecil. Hasil proyeksi konsumsi beras di Nusa Tenggara Barat untuk 5 tahun mendatang dapat disajikan pada Tabel 6.

Tabel 6. Proyeksi Konsumsi Beras di Nusa Tenggara Barat, 2019-2023

\begin{tabular}{cccc}
\hline Tahun & Periode & Nilai Ramalan & MAPE \\
\hline 2019 & 15 & 599.346 & \\
2020 & 16 & 609.448 & \\
2021 & 17 & 619.551 & \\
2022 & 18 & 629.653 & \\
2023 & 19 & 639.755 & $2,11 \%$ \\
\hline \multicolumn{5}{c}{ Nilai Kesalahan }
\end{tabular}

Sumber : Analisis Data Sekunder (2019)

Tabel 6 menunjukkan hasil estimasi konsumsi Beras di Provinsi Nusa Tenggara Barat tahun 2019-2023 dengan metode Double Exponential Smoothing oleh Holt. Proyeksi konsumsi beras selama 5 tahun mendatang mengalami peningkatan. Proyeksi konsumsi beras pada tahun 2019 sebesar 599.346 ton; pada tahun 2020 sebesar 609.448 ton; pada tahun 2021 sebesar 619.551 ton; pada tahun 2022 sebesar 629.653 ton; dan pada tahun 2023 sebesar 639.755 ton. Untuk mendeteksi ketepatan dari hasil nilai ramalan yang dibandingkan dengan observasi (data aktual) untuk metode peramalan data deret waktu perlu ditentukan nilai MAPE. Nilai MAPE minimum yang dihasilkan yaitu 2,11\%, yang berarti bahwa kemampuan peramalan dengan metode ini memiliki tingkat akurasi yang baik.

C) Perbandingan Proyeksi Produksi dan Konsumsi Beras di Nusa Tenggara Barat, 2019-2023

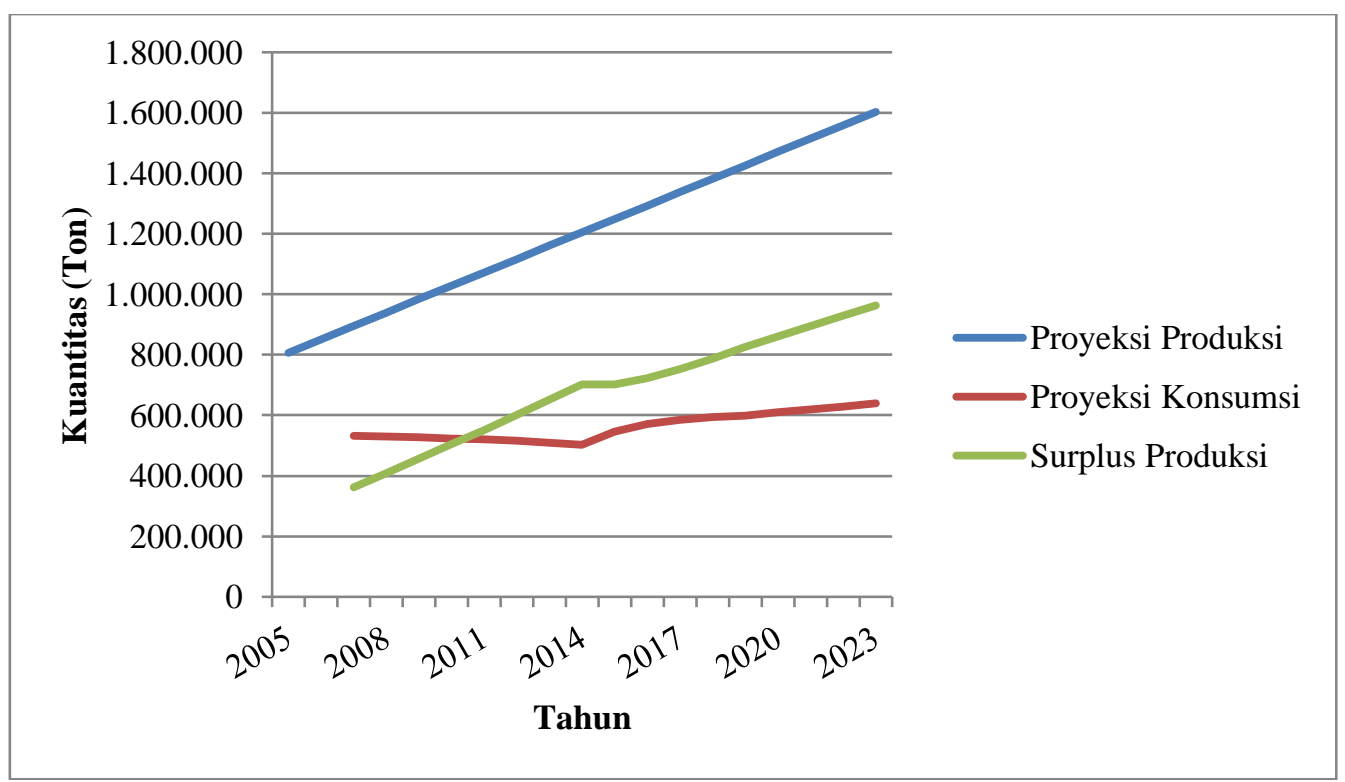

Sumber: Analisis Data Sekunder (2019)

Gambar 8. Perbandingan Proyeksi Produksi dan Konsumsi Beras di NTB, 2019-2023 
Gambar 8 menunjukkan perbandingan proyeksi produksi dan konsumsi beras di Nusa Tenggara Barat untuk tahun 2019-2023. Grafik diatas menunjukkan bahwa proyeksi produksi beras selama 5 tahun mendatang mengalami surplus produksi atau kelebihan produksi. Hal ini ditunjukkan oleh rata-rata produksi beras sebesar 1.204.669 ton, rata-rata konsumsi beras sebesar 562.053 ton/tahun, dan rata-rata surplus beras sebesar 686.889 ton. Dari segi produksi dan konsumsi beras secara umum mengalami peningkatan. Dengan adanya surplus beras ini menunjukkan bahwa produksi beras akan mencukupi kebutuhan beras di Nusa Tenggara Barat selama 5 tahun mendatang. Maka dari itu, diharapkan tingkat produksi beras dipertahankan dan dapat mencapai sesuai dengan yang diproyeksikan atau diperkirakan.

\section{KESIMPULAN DAN SARAN}

\section{Kesimpulan} berikut:

Berdasarkan hasil penelitian, dapat ditarik beberapa kesimpulan sebagai

1. Perkembangan produksi beras di Nusa Tenggara Barat dalam kurun waktu 14 tahun terakhir (2005-2018) mengalami fluktuasi, namun secara umum mengalami peningkatan. Produksi beras terendah di NTB terjadi pada tahun 2005 yaitu sebesar 772.421 ton, sedangkan produksi beras tertinggi terjadi pada tahun 2018 sebesar 1.409 .855 ton. Hal tersebut juga diikuti oleh perkembangan konsumsi beras di NTB. Tingkat konsumsi beras terendah terjadi pada tahun 2013 sebesar 504.240 ton/tahun, sedangkan tingkat konsumsi beras tertinggi terjadi pada tahun 2018 586.601 ton/tahun. Perbandingan jumlah produksi beras dan tingkat konsumsi beras di NTB menunjukkan adanya surplus produksi sebesar 556.194 ton.

2. Metode peramalan terbaik yang dapat digunakan untuk memproyeksikan produksi beras di Nusa Tenggara Barat tahun 2019-2023 adalah metode Trend Least Square, karena mempunyai nilai Mean Absolute Percentage Error (MAPE) terkecil, sedangkan metode peramalan terbaik untuk memproyeksikan konsumsi beras di NTB tahun 2019-2023 adalah metode Holt's Double Exponential Smoothing karena mempunyai nilai MAPE terkecil.

3. Produksi beras diproyeksikan sebanyak 1.425 .916 ton pada tahun 2019 dan sebanyak 1.602 .890 ton pada tahun 2023, dengan peningkatan sebesar 22.122 ton per tahun. Konsumsi beras diproyeksikan sebanyak 599.346 ton/tahun pada tahun 2019 dan sebanyak 639.755 ton/tahun pada tahun 2023. Produksi beras dalam 5 tahun kedepan mengalami surplus diatas konsumsi sebesar 686.889 ton per tahun. 


\section{Saran} berikut:

Berdasarkan hasil penelitian, dapat ditarik beberapa kesimpulan sebagai

1. Kepada pemerintah agar membuat suatu kebijakan yang dapat mempertahankan produksi beras baik segi luas lahan dengan memanfaatkan lahan terlantar, lahan marjinal, lahan perkebunan, dan lahan bekas pertambangan.

2. Penelitian ini menggunakan data sekunder yang memiliki kelebihan dan kelemahan. Kelebihannya yaitu dari segi biaya dan waktu memperoleh data lebih cepat, sedangkan yang menjadi kelemahannya adalah rendahnya pengetahuan terkait kejadian sebenarnya di lapangan. Diharapkan bagi peneliti selanjutnya yang ingin melakukan penelitian serupa, agar mampu mengimbanginya dengan berbagai informasi yang terjadi di lapangan.

\section{DAFTAR PUSTAKA}

Bowerman, B. L. \& O'Connell, R. T. 1987. Time Series Forecasting. Duxbury Press. Boston.

Markidakis, S. 1993. Metode dan Aplikasi Peramalan Edisi Ke-2. Bina Aksara. Jakarta.

Mashur. 2016. Revolusi Pangan: Membangun Kemandirian Pangan Untuk Kesejahteraan Petani. Polydoor. Jakarta.

Sawit, M.H. 2000. Arah Kebijakan Distribusi Perdagangan Beras dalam Mendukung Ketahanan Pangan: Aspek Perdagangan Dalam Negeri. Majalah pada Semiloka Penyusunan Kebijakan PerBerasan, 14-15 Maret 2000. Kerja sama LP-IPB dengan Ditjen. Tanaman Pangan dan Hortikultura, Bogor.

Sugiarto \& Harijono. 2000. Peramalan Bisnis. Gramedia Pustaka Utama. Jakarta.

Sungkawa, I. \& Ries T. M. 2011. Penerapan Ukuran Ketepatan Nilai Ramalan Data Deret Waktu Dalam Seleksi Model Peramalan Volume Penjualan PT Satriamandiri Citramulia. Corntech. 2[2]: 636-645. 